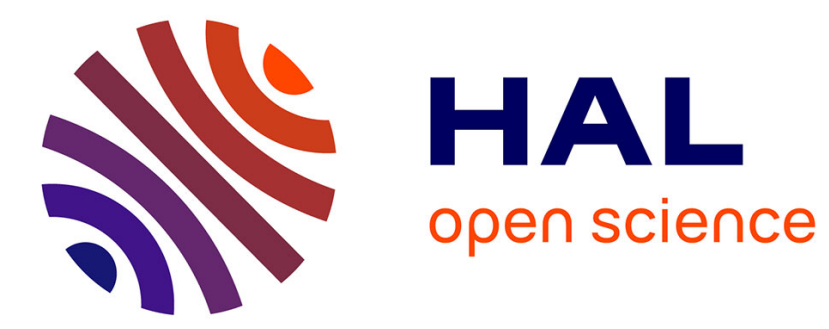

\title{
A canary in the Southern Ocean
}

Nicolas Metzl

\section{To cite this version:}

Nicolas Metzl. A canary in the Southern Ocean. Nature Climate Change, 2019, 9 (9), pp.651-652. 10.1038/s41558-019-0562-1. hal-02343935

\section{HAL Id: hal-02343935 \\ https://hal.science/hal-02343935}

Submitted on 15 Nov 2019

HAL is a multi-disciplinary open access archive for the deposit and dissemination of scientific research documents, whether they are published or not. The documents may come from teaching and research institutions in France or abroad, or from public or private research centers.
L'archive ouverte pluridisciplinaire HAL, est destinée au dépôt et à la diffusion de documents scientifiques de niveau recherche, publiés ou non, émanant des établissements d'enseignement et de recherche français ou étrangers, des laboratoires publics ou privés. 


\title{
A canary in the Southern Ocean
}

\author{
The Southern Ocean is a major carbon sink, but knowledge of its variability is limited, especially in the coastal \\ Antarctic. Now, results based on 25 years of observations in the West Antarctic Peninsula show that the carbon \\ sink is increasing rapidly, driven by summertime biological production linked to sea ice dynamics.
}

\section{Nicolas Metzl}

T wo centuries ago, when Captain Nathaniel Brown Palmer and his crew sailed around the Antarctic Peninsula, the concentration of carbon dioxide $\left(\mathrm{CO}_{2}\right)$ in the atmosphere was around $280 \mathrm{ppm}$ and the oceans were a net source of $\mathrm{CO}_{2}$ (ref. ${ }^{1}$ ). Since then, anthropogenic $\mathrm{CO}_{2}$ emissions have led to a marked increase of $\mathrm{CO}_{2}$ in the atmosphere, which reached $410 \mathrm{ppm}$ in 2019. Oceans have taken up a quarter of the anthropogenic $\mathrm{CO}_{2}$ (ref. ${ }^{2}$ ), slowing the rate of climate change. Without this ocean carbon sink, atmospheric concentrations would now be almost 500 ppm. However, it is uncertain how the marine $\mathrm{CO}_{2}$ sink will evolve in the future, given the complex coupling between physical, chemical and biological processes not yet well observed or represented in models used to simulate future climate ${ }^{3}$. To improve the predictions of these models, it is important to obtain long-term, multidisciplinary observations of $\mathrm{CO}_{2}$ dynamics in the Southern Ocean, where both warming and sea-ice changes alter the ocean stratification and the ecosystems that control the ocean's capacity to absorb carbon. Writing in Nature Climate Change, Michael Brown and colleagues ${ }^{4}$ present such observations and find a strong decline in surface water carbon.

The Southern Ocean and coastal Antarctic are particularly sensitive to climate changes that bring about changes in ocean circulation, mixing and phytoplankton productivity. All of these effects lead to variations in surface water $\mathrm{CO}_{2}$ concentrations and associated air-sea $\mathrm{CO}_{2}$ exchanges that need to be quantified before we can understand the link between environmental changes and the $\mathrm{CO}_{2}$ uptake capacity of the ocean. Although regular observations in the Southern Ocean are still sparse, recent studies suggest decadal changes of the Southern Ocean carbon sink at the basin scale ${ }^{5}$. This is, however, not well evaluated in seasonal ice zone and coastal regions ${ }^{6}$, highlighting the need to investigate long-term observations at a regional scale.

Brown et al. ${ }^{4}$ investigate 25 years of data obtained in the West Antarctic Peninsula

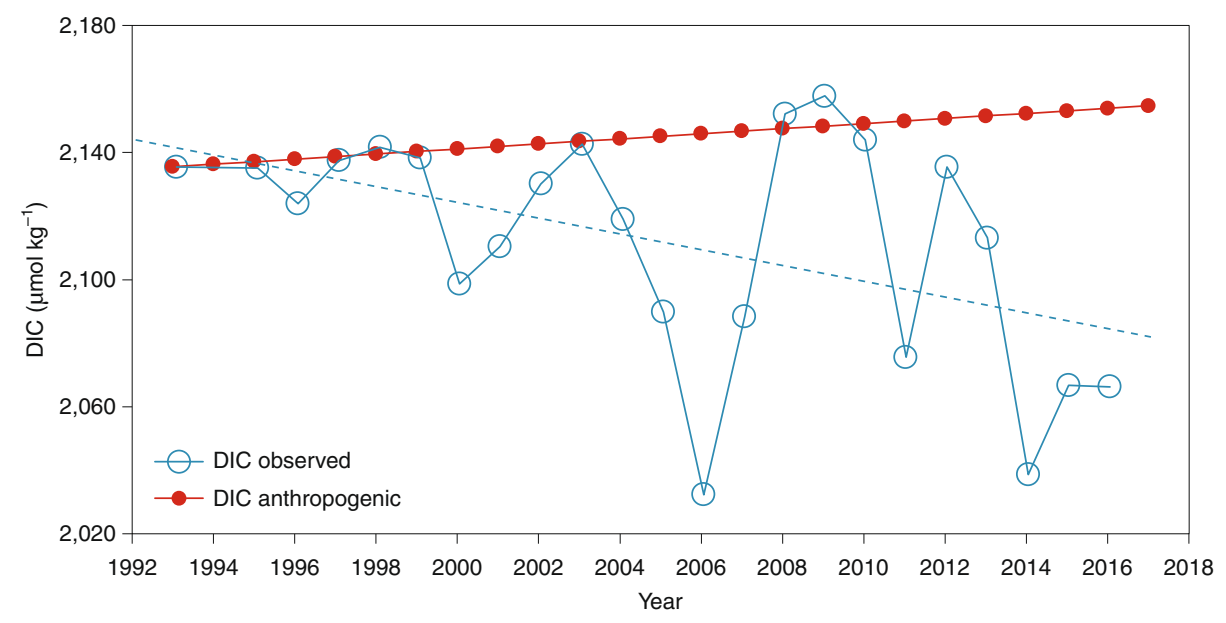

Fig. 1 | Mean dissolved inorganic carbon (DIC) concentration observed in surface waters in the West Antarctic Peninsula. Data for DIC concentrations (blue) are from observations ${ }^{4}$ each summer around $67^{\circ}-68^{\circ} \mathrm{S}$. The observed decrease is in contrast to the increase expected from anthropogenic $\mathrm{CO}_{2}$ accumulation only (red symbols and line). The strong decrease of DIC is due to phytoplankton productivity leading to an enhanced carbon $\operatorname{sink}^{4}$.

in the framework of the Palmer Long-Term Ecological Research (LTER) programme coupled to the Drake Passage Time-series programme. The region has long been recognized as an important $\mathrm{CO}_{2}$ sink in austral spring-summer, with surface values of $\mathrm{CO}_{2}$ pressure $\left(p \mathrm{CO}_{2}\right)$ as low as 100-150 $\mu$ atm (ref. ${ }^{7}$ ). Brown et al. show that this uptake of $\mathrm{CO}_{2}$ occurs every year from 1993 to 2017 and demonstrate a strong link between this $\mathrm{CO}_{2}$ sink, ocean stratification and primary productivity. In the Southern Ocean and Antarctic coastal zones, offshore primary production by phytoplankton is not limited by nutrients (except iron). In spring-summer, when the ocean warms and sea ice melts, the ocean stratifies with a shallow mixed layer, so that photosynthesis in this mixed layer is not light-limited. The resulting increase in primary productivity reduces the concentrations of dissolved inorganic carbon (DIC) in surface waters through a process known as the biological carbon pump. This leads to oceanic $p \mathrm{CO}_{2}$ well below atmospheric level, which means that the ocean can absorb more $\mathrm{CO}_{2}$. The carbon pump is strengthened when diatom species dominate phytoplankton communities ${ }^{4}$. Although the impact of primary production on the seasonality of the marine $\mathrm{CO}_{2}$ sink has been recognized in Antarctic coastal zones ${ }^{7,8}$, little is known about the temporal variability of this process.

Following recent work investigating long-term changes in the oceanic carbonate system in this region ${ }^{9}$, Brown et al. shed new light on the questions of how and why the ocean $\mathrm{CO}_{2}$ sink changes over time. In contrast to previous work, they separate the northern and southern regions, which are influenced by different forcing, and find significant differences in the regional responses - linked to the southward extent of climate forcing along the West Antarctic Peninsula. In the northern region, there was a small decrease in DIC (about $\left.-0.16 \mu \mathrm{mol} \mathrm{kg} \mathrm{kg}^{-1}\right)$, similar to previous studies ${ }^{9}$. However, a much greater decrease in DIC - up to $-2 \mu \mathrm{mol} \mathrm{kg}^{-1} \mathrm{yr}^{-1}$ - was 
identified in the southern region (Fig. 1), highlighting the contrasting response in the two subregions. This implies a strengthening of the carbon sink over more than two decades in the southern region during the austral summer.

Interestingly, the decrease in DIC is in contrast to the increase expected from anthropogenic $\mathrm{CO}_{2}$ accumulation $\left(+0.8 \mu \mathrm{mol} \mathrm{kg}{ }^{-1} \mathrm{yr}^{-1}\right.$ in surface waters at these latitudes (Fig. 1)). It is worth recalling that DIC concentrations in surface waters range between 1,900 and $2,200 \mu \mathrm{mol} \mathrm{kg}{ }^{-1}$, so detecting a trend of around 1-2 $\mu \mathrm{mol} \mathrm{kg} \mathrm{kgr}^{-1}$ needs very accurate measurements. The data presented ${ }^{4}$ were qualified at international standards ${ }^{10,11}$ and leave no doubt that the summer ocean carbon sink has increased rapidly since 1993 in the investigated region, driven by an increase in phytoplankton production, particularly from diatoms, related to ocean stratification.

Surface $p \mathrm{CO}_{2}$ generally increases at a rate of 1-2 $\mu \mathrm{atm} \mathrm{yr}^{-1}$ in most oceanic regions ${ }^{12}$ and the observed long-term $p \mathrm{CO}_{2}$ decrease of $-2.8 \mu$ atm $\mathrm{yr}^{-1}$ evaluated by Brown et al. is the most rapid negative trend recorded in the ocean. It will be important to follow this signal in the next decade to confirm the reaction of the carbon sink in Antarctic coastal regions to future declines in sea ice and shifts in phytoplankton communities.

This new analysis ${ }^{4}$ is an important step forward in our understanding of the complex interplay of physical, biological and anthropogenic processes that govern ocean carbon uptake in a region particularly sensitive to changes in local or remote forcing. Such a long-term study also presents a challenge for sensitivity testing and validation of models that attempt to reproduce ocean biogeochemical cycles and predict future climate changes.

The data from the long-term observational project Palmer-LTER, including the presence of certain phytoplankton species, could now serve to detect the impact of climate change in the Southern Ocean, like the canaries used in the coal mines of previous centuries. It is crucial to maintain such time-series and promote observations in other Antarctic sectors to compare responses in different regions where ice-melt or warming present different changes. Ship-based data should now be associated with new data from autonomous floats ${ }^{13}$ to better document the variations of the ocean carbon sink in all seasons.

Nicolas Metzl

LOCEAN-IPSL (CNRS/SU/IRD/MNHN), Sorbonne Université, Paris, France.

e-mail: nicolas.metzl@locean-ipsl.upmc.fr

Published online: 26 August 2019

https://doi.org/10.1038/s41558-019-0562-1

References

1. Brovkin, V. et al. Biogeosciences 16, 2543-2555 (2019).

2. Le Quéré, C. et al. Earth Syst. Sci. Data 10, 2141-2194 (2018).

3. Pilcher, D. J. et al. J. Geophys. Res. Oceans 120, 4625-4637 (2015).

4. Brown, M. S. et al. Nat. Clim. Change https://doi.org/10.1038/ s41558-019-0552-3 (2019).

5. Landschützer, P. et al. Science 349, 1221 (2015).

6. Laruelle, G. G. et al. Nat. Commun. 9, 454 (2018)

7. Karl, D. M. et al. Deep Sea Res. A 38, 1097-1126 (1991).

8. Legge, O. J. et al. Deep Sea Res. II 139, 167-180 (2017).

9. Hauri, C. et al. Biogeosciences 12, 6761-6779 (2015).

10. Dickson, A. G., Sabine, C. L. \& Christian, J. R. Guide to Best

Practices for Ocean $\mathrm{CO}_{2}$ Measurements (PICES Special Publication 3, 2007).

11. Bakker, D. C. E. et al. Earth Syst. Sci. Data 8, 383-413 (2016).

12. Takahashi, T. et al. Deep-Sea Res II 56, 554-577 (2009).

13. Gray, A. et al. Geophys. Res. Lett. 45, 9049-9057 (2018). 